\title{
DIE NORMERING VAN AFRIKAANSE TAALGEBRUIK SOOS BEOEFEN IN DIE SKOOL EN DIE UNIVERSITEIT
}

\author{
J.P. Botha
}

1

Sienings van taaionderwysers en -dosente

Tydens hierdie kort ondersoek na "die normering van die gebruik van Afrikaans" soos dié praktyk beofen word in skole en ander onderwysingtangies het dit duidelik geword dat ' $n$ veel omvangryker ondersoek nodig sou wees om hoegenaamd die saak tot die been toe te kan analiseer en werklik bevredigende antwoorde op die talle probleme te probeer vind. Wat hier volg, is die resultaat van hierdie "voorlopige" ondersoek, en gedagtes wat die algemene probleem in verband met die normering van Afrikaans enigsins verder wil toelig.

Die ondersoek is gedoen deur onder meer vraelyste uit te stuur warin vrae soos die volgende gestel is:
(1) Hoe belangrik is die normering van Afrikaanse taalgebruik?
(2) Watter aspekte van Afrikaanse taalgebruik betrek u by normering?
(3) Watter bronne gebruik $u$ as norm, en waarom?
(4) Hoe word die effektiwiteit van die normering gekontroleer, en hoe reageer u daarop?
(5) Wat is die uiteindelike doel van die normering?
(6) Watter probleme ondervind $u$ met hlerdie faset van u werk?
Die vraelyste is voltooi deur persone wat Afrikasns doseer (het) (aan pri- mêre/sekondêre/tersiêre inrigtings) en wat almal jarelange ervaring in die verband het. 
Almal erken die Taalkommissie as die amptelike gesag sover dit spellingnorme betref en deurgaans word die staf-Afikanse axademie vir wetenskap en Kuns se jongste Afrikaanse woordelys en spelreäls aangegee as bron.

Die oogmerke wat gestel word met normering is hoofsaklik taalsuiwerheid, verstaanbarheid, uitskakeling van dubbelsinnigheid, logiese en duidelike oordra van gedagtes (mondeling sowel as, en veral, skriftelik) en doeltreffende stelwerk, wat neerkon op korrekte taalgebruik. Een van die taalonderwysers vat dit só saam:

"Die volkseie is toelatbaar en die volksvreemde is verkeerd".

Afgesien van die persoonlike leiding en oordeel van die vakonderwyser is die leerlinge en studente aangewys op die geduriqe gebruik van verklarende woordeboeke soos die WAT en die aAT, verskeie tweetalige woordeboeke en allerlei handboekies wat veral handel oor spellingprobleme, tot die keuse van die "korrekte woord". Daarbenewens speel die betrokke "taalhandboeke" en die "voorgeskrewe werke" natuurlik ook 'n groot rol.

Alle Easette van taalgebruik is betrokke by normering: mondelinge gebruik, skriftelike stelwerk, lees, taalleer (basiese formele taalaspekte soos byvoorbeeld voorgeskryf deur die onderwysdepartemente), taalvaardigheid of taalgebruikskunde en literatuurstudie. En die plig/opdrag van die taalonderwyser is om toe te sien dat die leerling/student op só 'n wyse gelei word dat laasgenoemde die taal, mondeling en skriftelik, so ver moontlik korrek en doeltreffend sal gebruik. Dit gebeur aan die hand van aanbieding, toepassing, kontrole, prys, verbetering, berisping waar nodig, en veral die lewende voorbeeld wat die talonderwyser moet. wees, en die liefdevolle erns, hulpvaardigheid en entoesiasme warmee hy sy vak aanbied.

Gedurig onder die loep is: uitspraak, woordkeuse vis dié besondere talregister, frasering, intonasie cof sal ek liewer sê: die regte "wysie" vir " $n$ spesifieke sin of uiting), spelling, los-en vasskryf van woorde, volgorde en sinsbou. Dit hang naturilik saam met meervoudsvorming, verkleinwoorde, trappe van vergelyking, ou verboë vorme, nuutskeppinge en die gebruik van hoofletters en leestekens.

Die peil van ontwikkeling en die norme wat ter sake is, word natuurlik in die leerplanne uitgestippel, en. word weerspieël in die eksamenviaestelle wat viteindelik as die toetssteen dien. As gevolg van jarelange ervaring 
word die vraestelle van die "Eindeksamen van die Middelbare skool" uiteindelik die algemene norm wat die taalonderwyser minstens probeer bereik.

Die toetsing van die effektiwiteit van sy normering geskied feitlik daagliks --- veral ten opsigte van skriftelike werk--- deur kommentaar, nasien van geskrewe werk, spesifieke stelwerk, toetse en uiteindelik ook eksamenwerk. Aangeduide foute moet verbeter word, swak stelwerk moet herhaal en verbeter word, en algemene foute word met die hele klas bespreek en die korrekte "stelwyse", "antwoord", ensovoorts word gegee en gemotiveer. Die onderwyser inisieer dus die een of ander taalbedrywigheid, korrigeer die reaksie en probeer daarop voortbow in die daaropvolgende taalbedrywigheid.

Velerlei faktore bemoelik die taalonárwyser se taak. Ek noem hier ' $n$ paar van die sake wat in dié verband aangedui is:

Al is élke onderwyser, volgens die Af ondeswyser, steur min ander onderwysers hulle aan die taal wat die leerlinge gebruik in hulle werkstukke, en selfs ernstige taalfoute word dikwels nie eers onderstreep nie. Die verskoning is blykbaar: "Dis die werk van die taalonderwyser".

Dit wil voorkom asof leerlinge al minder ' $n$ erg het aan suiwer taalgebruik, laat staan nog die estetiese. ('n studie van letterkunde baat hom byvoorbeeld niks, want dit gaan hom nie meer geld in die sak besorg nie!)

Norme wat deur die onderwyser gepropageer (of "afgedwing") word, is vir die meeste leerlinge slegs van belang om die eksamen te slaag. Buite die klaskamer praat hy maar soos hy wil.

Wat die uitspraak en aksentuering van alledaagse woorde betref, staan die onderwyser met sy rug teen die muur. Leerlinge kan of wil nie die korrekte aanvaar nie, want niemand praat dan só nie. Boonop is die Anglisistiese vorme dikwels vir hulle meer aanvaarbaar. Engelse invloed het beslis in negatiewe uitwerking op die normering van die gebrulk van afrikans.

Idiomatiese talgebruik en veral idiome kom feitlik nog net voor in die taaloefening. selde in die algemene spreektal en soms in leerlinge se skryfwerk. 
Omdat die taalhandboeke, veral op die huidige oomblik, nie net verouderd is nie, maar hoegenaamd nie tred gehou he met die ontwikkeling van die taalkunde die afgelope dekades nie, is die stof self dikwels verouderd en is die terminologie en benadering ten opsigte van die taalkunde nie net verpuderd nie, mar dikwels foutief. Dit geld veral ten opsigte van sinne, bysinne, rededele, ensovoorts.

Veral terme ten opsigte van die taalkunde behoort gestandaardiseer te word en dit sal noodgedwonge meebring dat heelwat verouderde beskouings en benaderingswyses oorboord gegooi sal moet word. Onderwysstudente wat Afrikaans as hoofvak op universiteit gehad het, kan tans beswaarlik hul swaarverwerfde kennis in die skool toepas of gebruik, omdat die leerplanne slegs voorsiening maak vir taalkundige beskouings en benaderings van dekades gelede. Sulke nuwe taalonderwysers word dus verplig om "maar te vergeet wat hulle op universiteit geleer het" en moet weer terugsak in die ou-ou duisternis.

In die lig van bogenoemde beswar van die taalonderwysers se kant, is dit nou duidelik warom eerstejaars soveel anpassingsprobleme op universiteit het veral ten opsigte van die taakunde. Geen wonder dat hulle verstom staan om te hoor dat daar nie "net tien woordsoorte" in Afrikaans is nie, of dat daar meer klasse hoofwerkwoorde is as warvan hy weet, of dat sinne hiërargies gestruktureer is, of dat daar gramatieskontroleerbare bande bestaan tussen sekere sinne, bysinne, klouse, ensovoorts. Om nie eens te praat van die misleidende of selfs foutiewe benaminge soos "byvoeglike naamwoord", "hulpwerkwoord van die lydende vorm", ensovoorts waarvan hulle op skool moet leer nie.

Hierby voeg ek nog die volgende aktuele probleem wat taalonderrig op skool ten nouste raak:

Is die taalonderwyser aan die hoërskool nie die mees oorwerkte en onderbetalde wese in die onderwys nie? Wie neem in aanmerking dat die persoon wat Afrikaans of Engels doseer nie 'n keuse-vak doseer nie? Hy moet regstaan vir almal. byvoorbeeld ál die standerd sewes en ál die standerd tiens in die skool, en sy klaskamer sit altyd vol (of oorvol) leerlinge wat verplig word om sy vak te neem, of hulle wil of nie, en hulle sorg daagliks vir hope en hope nasienwerk vir die onderwyser. Benewens die gewone taalgebruiksoefening, begripstoetse. ensovoorts moet elkeen weekliks of tweeweekliks ' $n$ stuk stelwerk doen, en as net drie van die klasse op ' $n$ dag 
http://spilplus.journals.ac.za/

hulle "opstelle" ingehandig het, sit die onderwyser met ongeveer negentig tot honderd-en-twintig skrifte wat hy baie noukeurig moet nasien en beoordeel. Voeg hierby nog die letterkunde-opstelle wat veral van standerd agt af begin vermeniguldig, met al die sienings en/of mistastings oor karakters, styl, beelding, ensovoorts daarin, en wat "reggedokter" moet word deur die onderwyser. En wie dink daaraan dat die taalonderwyser, soos enige ander onderwyser, sy plek volledig moet volstaan by al die buitemucse bedrywighede van die skool tatletiek, netbal, rugby, kadette, Boy Scouts, voortrekkers, ensovoorts) en dan kry hy gewoonlik nog daarby die debatsvereniging, die skool se jaarblad, die verskillende redenaarskompetisles en die skoolkonsert of -operette op die koop toe as deel van sy verantwoordelikheid?

As ' $n$ mens al dié probleme in aanmerking neem, moet jy jou hoed afhaal vir dié mense. Dat hulle ten spyte van die leerplanne en die veeleisende, problematiese omstandighede nog in bruikbare produk lewer, is beslis in prestasie. Dit is duidelik dat die goeie taalonderwyser gekortwiek word deur talle probleme buite sy beheer.

Die sin van taalondercig is daarin geleë dat die leerling kan toetree tot die geledere van persone wat binne ' $n$ bepaalde milieu ' $n$ "afspraak" nakom betreffende simboliese betekening en kommunikasie, en hom daar tuis voel en diensbaar kan maak. Taal as "afspcaak" veronderstel 'n norm. 'n Norm

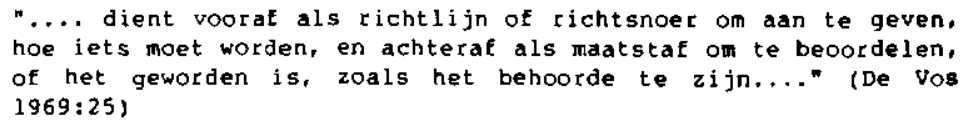

By die formulering van die belangrikste doelstelling van eerstetaal-taalkundeonderrig, namlik "... die bevordering van die leerling se vermoë om die taal doeltreffend en korrek te gebruik" (TOD-Billabus vir Afrikaans, eerste taal), verloor die formuleerders uit die oog dat taalkunde-onderrig in opvoedingsverband moet geskied. Dit behoort op die verwesentliking van volwassenheid of gevormheid (hier: taalgevormdheid) gerig te wees. Dit impliseer nas kennis ook kundigheid, vaardigheid, verantwoordelikheid en veral genormeerdheid. 
"n Mens sou dus eerder die volgende vormingskategorie as einddoel van die opvoedende taalkunde-onderrig wou daarstei: Om die moedertal bewustelik onder norm van noukeurigheid, suiwerheid en Eunksionaliteit te kan gebruik." (Swart 1983:146)

Wanneer daar in die gesprek condom taal melding gemaak word van "normering van taalgebruik" word daamee gewys op aantoonbare kragte of individue of groepe in die samelewing wat bewus is van leemtes, afwykings of skeeftrekkings in die taalgebruik. Binne elke groter of kleiner taalgemeenskap bestaan daar die neiging om ' $n$ taal te standaardiseer. Oor hierdie eienskap van taal het stutterheim reeds duidelik aangedui:

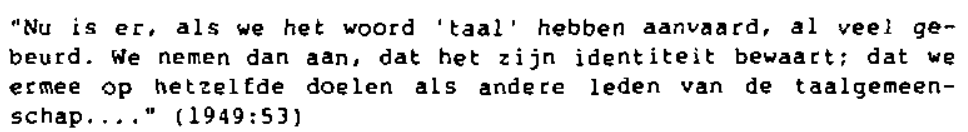

Formele taalonderrig op skool het veral te make met die ontsluiting van die mens se gees vir sover dit sy logiese en analitiese geestesbedrywigheid betref. Die subjektief-logiese werksaamheid van die mens se gees stel hom in staat tot warneming van, insig in, begrip van, reaksie op en deeiname aan die taalwerksaamheio soos dit in die gemeenskap bestan. Hierdie formele en gerigte ontsluiting wat die onderrig voor oë het, stel die mens vecal in staat om die taalaspek uit die kosmiese verskeidenheid om hom heen te abstraheer as kenbare objek.

Die onderrig van taal is dus altyd aan die eise van funksionaliteik onderworpe. Die taalonderwyser moet homself gedurig daarvan vergewis van hoe sy taalonderrig bydra tot die leerling se taalgebruiksvardigheid, maar ook van die mate warin dit bydra tot die leerling se identieitsverwerwing. Hoe hy dit ook al doen, en water teoretiese modelle hy ook al mag gebruik, staan normatiwiteit en die aanlê van norme altyd sentraal in die gesigsueld.

Die besondere verwerkliking van linguistiese beginsels en strukture in die taal vorm die fokuspunt en doel van taalonderrig. Onderskeiding van die besondere, en dikwels unieke strukture van die taal beteken terselfdertyd anderskelding van die afwykinge daarvan. Vanuit in taalonderrigstandpunt sou sodanige afwykinge gesien word as afwykinge van die norm. 
Veral twee aspekte van normatiwiteit in die taalonderrig verdien nadere bepaling. Normatiwiteit in die taalonderrig dui tegelyk op linguigtiesoutentieke inhoud en wyse van pnderrig, en andersyds op sensitiwiteit vir en begrlp van die eieaard en identiteit van Afrikaans.

Daar sal altyd allerlei talmodes wees. Daarom sal daar van tyd tot tyd voorstanders wees van die mode on so "vry" as moontlik met die taal om te gaan asof daar nie norme bestaan nie, asof anglisismes slegs 'n spook is en asof dit in sonde is om jou te steur aan die bestaan van AB-Afrikaans. Dit laat my altyd dink aan wat my wonderlike kunsonderwyser, mnr. p.H. Leuschner, jare gelede oor sekere neigings in die destydse "moderne" kuns gesê het:

"Sulke 'xuns' is die vermoë om jou onvernoë te verberg".

Dit bly steeds die plig van die taalonderwyser om sover moontik volgens die norme wat oor baie jare heen neergelê is, die ontwikkeling van sy leerlinge se talgebruik te rig.

Gesproke taal is baie meer as bloot ' $n$ kommunikasiemiddel indien ' $n$ mens dit vergelyk met kommunikasiemiddele soos die telefoon, die radio, die teledrukker, televisie, ensovoorts. Omat die mens ' $n$ sosiale wese is en die gawe van sprak besit, vind daar gedurig kommunikasie taalsgewys tussen mense plaas -- wat ook al die inisieerder van elke gesprek of monoloog mag wees. En die taal wat die komaunikasie tussen twee of meer mense moontlik maak, is nie ' $n$ kommunikasiemiddel nie, mar verteenwoordig die kommunkasie self, want, indien die noorder die vorm en volgorde van die onderskeie taalklanke wat gebruik word, herken as taal (wat hy ken), bestaan die moontlikneid dat hy sal verstaan wat die spreker gesêt het. Die taalgebruiker kan boonop verskillende registers van die taal ooptrek na gelang die sosiale omstandighede dit vereis. ' $n$ Afrikaansprekende kan sy taul gebruik om die allerteerste, intiemste, naïfste gevoelens, verlangens, wense, ensovoorts aan sy geliefde oor te dra, en die verfynde woordkunstenaar en digter, N.P. van Wyk Louw, kon met sy taal 
"... die heil'ge, nooit-gehoorde

dinge sê, warvoor die mense

huiwer, en wat om die grense

Elikker van my duister woorde".

(Grense in Alleenspraak)

Om mekar te kan verstaan, moet daar vir elke spreker en hoorder dus sekere konvensies bestaan wat nie buite perke van mekaar verskil nie, sodat die bedoeling van die spreker, en die weergawe darvan soos in die hoorder se verstand ontvang, nie basies van mekaar sal veskil nie. Stemtoon, aksentuering, handgebare, ensovoorts kan alles bydra tot beter begrip van wat die spreker wil oordra an die hoorder.

Geskrewe taal is ' $n$ onvolkome dog nodige surrogat vir die gesproke taal -. - om baie redes. Die belangrikste redes is seker dat dit wat gesê (kan/kon) word redelik permanent in woorde op papier, ensovoorts "vasgevang" word in geskrewe taal, sodat dit later, en boonop herhaldelik, gelees en begryp kan word deur ' $n$ leser, wat nou die plek inneem van die hoorder en gespreksqenoot tydens 'n gesprek. Geskrewe taal kan dus deur 'n persoon in afsondering gebruik word om te sê wat hy te sề het. ' $n$ Onmiddellike gespreksgenoot hoef dus nie fisies byderhand te wees nie. Boonop is die geskrewe taal fisies draagbar, vervoerbaar, vermeniguuldigbaar en brulkbar vir diegene wat darin belangstel ... al woon hulle waar ook al.

Dié kort oorsig oor gesproke en geskrewe taal is in alle opsigte ' $n$ oorvereenvoudiging, maar ek wil graag die aandag vestig op die uiters belangrike verskfl tussen die twee sake: war die gesproke taal gerugsteun kan word dewr allerlei hulpmiddele on doeltreffend te kan wees (stemtoon, aksentuering, gebare, ensovoorts), is die geskrewe taal aangewys op die tipografiese tekens op die skryfmateriaal. Tydens 'n gewone gesprek kan die spreker, so gou as wat hy ontdek dat sy hoorder(s) nie korrek verstaan wat hy bedoel nie, sy uiting(s) herhaal, dit op ' $n$ ander wyse stel of dit selfs verder toelig met ' $n$ verduideliking. Die leser het meesal nie dié voorreg van die hoorder nie, omdat die skrywer van 'n geskrewe stuk nie byderhand is om te sê: "Nee, maar nou verstaan jy my verkeerd! Ek bedoel eintlik...." nie. Dikwels leef die skrywer nie meer nie en kan jy nie eers, ná jou lees, hom probeer opspoor om uit te vind wat hy eintlik bedoel het nie.

Dáárom is dit so noodsaaklik dat elke skrywer se skryfwerk presies moet sî wat hy bedoel om te sê. En daarom moet hy hom hou aan die norme wat vir die 
http://spilplus.journals.ac.za/

spesifieke skryftaal geld. Dacom word 'n kind van kleins af geleer hoe om woorde korcek te spel, hoe on "nuwe" woorde te vorm deur samestelling en/of afleiding, hoe sekere woode in sy tal geneig is om in vaste groepe op te tree, en hoe om met behulp van dié boustene sinne te bou wat sinvol is. Die enigste rede warom 'n mens lieer skryf, is dat jyself, of veral iemand anders, later weer dieselfde gedagtes, wense, feite, ensovoorts uit daardie betrokke stuk skrywerk sal kan "optower" met sy leesvaardigheid, as wat hy daar ingesit het met sy skrywery, en darom kan normezing van skriftelike taalgebruik as die ruggrat van talonderrig beskou word.

Aanvanklik is die talonderrig op skool mondeling van aard en geskied normering dus mondeling, mar die gebruik van die skryfbord, truprojektor, flitskaarte, leesboekies asook die gebruix van pen en papier kom spoedig by. Nog later kom allerlei handboeke by en veral woordelyste, woordeboeke en spelreëls. Die goeie taalonderwyser gebruik meesal alle moontlike hulpmiddels om die norme wat geld ten opsigte van die verskillende aspekte van die betrokke taal so permanent as moontlik by die leerlinge tuis te brlng. Hy sal sy leerling ook gedurig verwys na boeke, tydskrifte, die radio, televisieprogramme, ensovoorts en hulle krities probeer instel om altyd te onderskei tussen "swak" en "goeie of korrekte" taalgebruik, en hulle aanmoedig on daarna te streef om so na as moontlik aan die teiken te kom met hulle taalgebruik --- in nierdie geval: Algemeen Beskafde Afrikaans.

Veral die voorskriftelike onderrigstelsel van laer-en hoërskole bring mee dat normering daar in baie groter rol speel as byvoorbeeld op universiteitsulak. Dit beteken natuurlik nie dat normering op universiteitsulak wegual nie, want sekere norme wat op skool ingedril en angeleet is, het terselfdertyd deur die jare heen feitlik in vanselfsprekendheid geword by die skoolverlater. Veral sekere aspekte van taalgebruik is vir hom doodgewoon 'n konvensie.

(a) Daarom hinder dit die meste mense Indien hulle in die praktyk skielik vind dat hulle nie seker is hoe ' $n$ spesifieke woord gespel moet word nie of warvoor ' $n$ sekere afkorting staan nie, ensovoorts. Van Graad 1 (Sub A) af word die norm van die korrekte spelwye van woorde aan kinders voorgehou. volgens die leerplan vir afrikaans is elke onderwyser in die eerste instansie ook taalondecwyser. Darom word dat van almal verwag on 
toe te sien dat die leerlinge reg spel en skryf. Die taalonderwyser het gewoonlik minstens in woordeboek wat asperon gebruik word. Veral in die hoëc standerds word allerlei woordeboeke gebruik asook die Afrikaanse woordelys en spelreëls van S.A. Akademie vir Wetenskap en kuns, en dikwels ook lyste spelwoorde en afkortings wat die leerlinge van buite moet ken. In sulke spellyste word dikwels woorde opgeneem wat beskou word as "slaggate vir die eksamen" soos: onmiddellik, komissle, komitee, benodigdhede, hidroëlektries, tetraämilose, anti-intlasieceëling, non-aktiviteit, toeeien, Van Riebeeck- mediese gebou, pronk-ertjie, skuuste, Marais's, geribde, aangehegte, ingelegde, lewenskets, kiepersol, familie, hendikep, defaitis, ensovoorts. Die resultat is dat dié woorde deur sommiges goed onthou word en dus reg gespel kan word terwyl dieselfde mense die volgende spelfoute begaan: sonet, ligaam, standardiseer, gallery, dieêt, finansieël, êcenstig, totsiens, ensovoorts. Die konvensie om korrek te spel, verteenwoordig seker die sterkste resultat van normering.

Ná spellirg volg onder meer die volgende fasette van taslgebruik:

(b) Los- of vasskryf van woorde soos die volgende: die hond, "n blom, hlerdje seun, rooi rosies, halwe lemoen, kom hier, ensovoorts.

(c) Woordgroepe soos langs die pad, voor die skool, in die daw, die twee donkies, 'n hele dag, groen soos gras, so droog soos horing. huis aan (die) kant eak, ensovoorts.

(d) Daarmee gaan naturlix gepard korrekte woordvolgorde in sinne en die gebruik van hoofletters en leestekens:

Don koos rook 'n pyp. Tante mak botter. Dit word gewas in 'n skottel.

(e) Die korrekte en beter woordkeuse:

Die onderwyser staan voor die swartbord (in plaas van

die man staan voor die swartbord).

Vandag is almal teenwoordig/aanwesig (in plaas van hier).

Ek noet ay verbeteringe doen (in plaas van my some or doen en reg maak").

simpatiseer met naasbestaandes; redeneer oor ' $n$

saak, hewige rusie, ensovoorts. 
http://spilplus.journals.ac.za/

J.P. Botha 355

(E) Vermyding van Anglisismes en ander "taaleuwels":

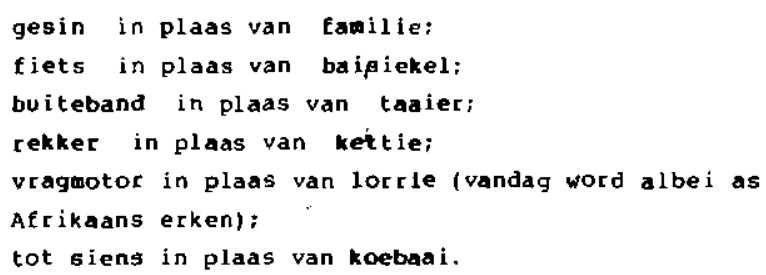

(9) Woordvorming deur afleiding, samestelling en samestellende afleiding: perdestal, druiweprieel, draadspringer, klipgooier, sementaanarakplek, ver keerdelik, ryswieragtig, onveranderlik, duivehokke, skeepsvragversekeraars.

(h) Afhanklike sinsvolgorde: dat hulle vandag die geweer aag saaneem; of daar vir haar ook ' $n$ matjie sal vees; ondat die wind nou verkeerd vaal; on gou-gou eers ' $n$ stukkie kos in te pak.

(i) Nr. (c) word later uitgebrei deur spreekwoordelike taalgebruik: tou opgooi, hand aan die ploeg slaan, iesand se brood uit sy wond neea, voet by stuk hou, die eamer skop, heuning ow die mond seeer, 'n cog op iesand hê.

(j) Al die verskillende aspekte van normering het natuurlik ten doel om taalvaardigheid (mondeling en veral skriftelik) so naby as moontlik op die peil van die $A B-A f r i k a n s$ te bring --- war $A B-A f r i k a a n s$ verwys na dit wat deur die belangrikste groep $A B$-sprekers gepraat word.

AB-Afrikaans verwys na dié litspraak wat die minste ' $n$ spreker se geografiese herkoms, in S.A. veral, verraai. AB-Afrikaans is hoogstens ' $n$ teoretiese ideaal om na te streef -- besmoontlik is daar niemand wat deurentyd, volledig en in álle opsigte AB-Afrikaans praat nie, maar dle aanvaarding van hierdie "standaardtaal" as doelwit van veral die skoolopleiding sover dit Afrikaans betref, veronderstel ' $n$ stel norme waraan daar gedurig, willens en wetens, of onwetend, die taalgebruik van Af $\mathrm{r}$ ikaanssprekendes gemeet word.

' $n$ Zewende taal kan nie onveranderd voortbestaan nie; daar moet nuwe blare, blomme en vrugte kom, dooie hout en takkies moet reggesaag en -gesnoei word. Gelukkig is taalverandering in langsame proses waarvan die solsoene oor dekades heen (of langer) strek --- anders sou die taalkundlge 'n baie moeiliker taak gehad het on orde uit die chaos te probeer skep. Voorskrif- 
telike normerende taalonderwys dra baie dactoe by dat taalverandering langsamer plaasvind as wat die geval daatsonder sou gewees het.

' $n$ Taalkundige wat dus Afrikaans as studieobjek het en die taal wil beskryf, sal dus meestal besig wees om die grenslyne en wesenstrekke wat normering daargestel het na te trek, en indien hy werklik al die nocme ken, sal hy die gouste enige "groei" of "agteruitgang" (hoe dit ook al op daardie oomblik mag lyk) in sy studieobjek raaksien en kan beskryt.

Dit is moeilik, of selfs onmoontlik, om enigsins akkuraat vas te stel in hoeverfe die doelstellings van normering aan die einde van 'n leerling se skoolloopbaan bereik is. ' $n$ Hoë persentasiepunt wat 'n leerling vir Afrikaans (Hoër graad) in die matriekeksamen behaal, behoort egter ' $n$ betreklik hoë korrelasie te toon met die mate warin normering in sý geval doeltreffend was. Normalweg is dit dan ook so dat ' $n$ leerling wat ' $n$ onderskeiding in Afrikaans in dié eksamen behaal, nie net ' $n$ goeie student is nle, mar ook goed kan spel en geen of baie min probleme ondervind met die volgende fasette van taalgebruik: woordbou, sinsbou, bysinne, funksionele gebruik van stylmiddele en stelwerk. Daarteenoor is dit nie meontlik om ' $n$ swak prestasie in die matciekeksamen bloot aan onderig wat met swak normering gepaard gaan, te wyt nie, want die swak prestasie kan baie ander oorsake hê congemotiveerdheid, gebrek aan belangstelling, luiheid, gebrek aan insig, ensovoorts).

Dit is wanneer die skoolverlater begin werk of studeer dat ' $n$ mens dikwels die klagte oor "swak taalgebruik" verneen. Die soort klagtes kom veral van instansies vir wie korrekte en doeltreffende taalgebruik belangrik is soos universiteite, kolleges, die statsdiens, sekere Afrikaanse sakeondernemings, instansies soos byvoorbeeld die F.A.K. en die A.T.R.V., kerkkantore, drukkers en uitgewers, ensovoorts. Ek het selde of nooit klagtes oor swak taalgebruik aangehoor in verband met skoolverlaters wat in diens geneem is deur die volgende instansies: kafees, restaurante, hotelskole, fabrieke, die motor- en talle ander nywerhede, private besigheidondernemings, ensovoorts. Sommige munisipaliteite, mynmaatskappye en banke kla wél by geleentheid. Min of geen klagtes korreleer egter in dié gevalle nie met "goeie resultate van normering" nie --- inteendeel! Dit is meesal ver- 
http://spilplus.journals.ac.za/

stommend on te sien hoe uiters swak die woordeskat, speling en sinsbou van slegs die volgende is:

-- 'n vakleerling (selfs werktuigkundige) wat vir jou 'n verslag(gie) moet opstel oor wat met jou imotor/wasmasjien/stoof/televisiestel, ensovoorts skort;

-- 'n verkeerskonstabel wat vir jou 'n verkeerskaartjie moet uitskryf ;

-- in konstabel wat 'n verklaring ooc 'n ongeluk afneem;

- 'n winkelassistent wat jou rekening samstel.

Dit vestig die aandag daarop dat slegs die swak taalgebruk van diegene wat soms verplig is om hulle hand op papier te sit van tyd tot tyd aan die lig kom. Die ander s'n kan natuurlik nog swakker wees én deterioreer vanwez̈ onbruik -- en dié warskynlikheid is groot. Die oorgrote meerderheid van dié soort gevalle is toonbelde van normering wat verreweg nie volledig geslaag het nie.

Omdat universiteite en kolleges hopelik veel hoër eise aan hul studente stel sover dit taalgebruik betref, behoort dié studente se swak taalgebruik, vanweë hul enigsıns akademiese gemotiveerdheid, nog beter te wees as dié van die vorige kategorie. Afgesien van almal wat wel oor ' $n$ goele taalvardigheid beskix en goeie taalgebruik beoefen, dui alles darop dat daar 'n ontsaglik hoë persentasie mense is warvan die taalgebruik swax is of minstens onder verdenking staan.

Indien dit vir Afrikaanse universiteite nodig is om te $x$ la oor veral eerstejaars se swak taalgebruik, is dit nog veel meer so ten opolgte van pas ingeskrewe Unisarstudente, ondat afrikaans vir húlle baie keer nie die moedertaal nie, maar dikwels ' $n$ tweede, ' $n$ derde en soms selfs ' $n$ vierde taal is! Indien ' $n$ mens aanvaar dat daar Afrikaansprekende studente is wasuan die taalgebruik as "swak" geklassifiseer word, kan jy verwag dat 'n groter persentasie van diegene vir wie Afrikans nie die moedertal is nie. in nog swakker taalgebruik sal openbaar --- en by Unisa blyk dit wel die geval te wees.

Teoreties behoort ' $n$ eerstejaarstduent, sonder dat daar veel aandag aan hom bestee word sover dit die basiese normering betref, direk met meer 
http://spilplus.journals.ac.za/

gevorderde werk as dié wat hy in matriek gedoen het, te kan voortgaan, maar in die praktyk is dit selde moontlik, ex, moet dar baie van die dosent se tyd onnodiglik vermors word met remediërende werk ten opsigte van die student se probleme met spelling, woordbou, sinsbou en stelwerk.

Op 8 Mei 1985 is daar as deel van die Onderrigontwikkelingsprogram van Unisa, ' $n$ seminaar gehou oor Die eerstejarstudent. Tydens dié seminaar is veral die uitsakking van nuweling eerstejaarstudente, wat vir die universiteit ' $n$ groot bekommernis is, vanuit verskillende hoeke toegelig. Veral die bydzaes van prof. A.D. Adey (departement Engels) en prok. K.J.H. Landman (departement Afrikaans en Nederlands) sluit aan by die probleme wat in hierdie artikel bespreek word, en ek maak dankbar gebruik van hul menings en bevindings in dié verband. (Die referate van proff. Adey en Landman verskyn binnekort in progressio vol.7, nt. 2, 1985 (Joernaal van die Buro vit Onderrigontwikkeling, Unisa)).

Prof. A.D. Adey van die departement Engels het gesê dat die taalgebtuix van eerstejaars varieer van baie goed tot baie swak.

"It is the latter, the very bad, whom I refer to as orphans and who, increasingly, take up a disproportionate allocation of the available time." (Adey 1985:1)

Hy wys daarop dat die woord "remedial" 'n belangrike deel van sy departement se woordeskat geword het, en hy vra of dit nie beter sou wees indien dosente hulle aandag liewer sou toepsits op die studente wat so ongeveer 68 behal en dit dan probeer opskuif na 75 nie, in. plaas daarvan om die veertigpersenter met ' $n$ gestoot en geflikflooiery te probeer opskuit tot, sê. 448 .

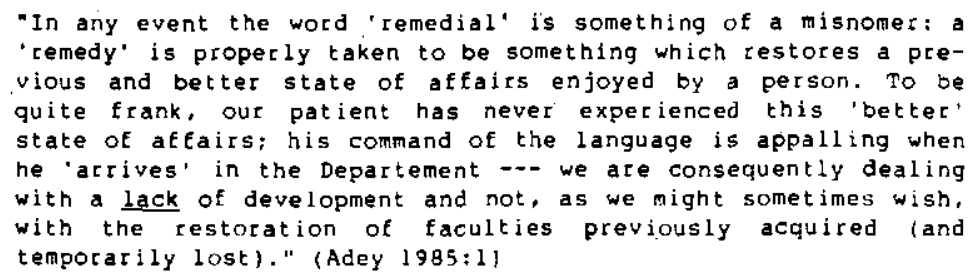

Dit is duidelik dat ons hier te make het met gevalle war normering van taalgebruik hopeloos ontoereikend was. 
http://spilplus.journals.ac.za/

Prof. Adey wys voorts darop dat dit niks bat om die skole te blameer nie. Twintig jaar gelede was dit nog standardpraktyk om leerlinge te leer hoe om die strukture van sinne te ontleed. Leerlinge moes die tradisionele woordsoorte ken, hulle moes onderwerp en predikat kon onderskei asook tussen verskillende tipes bywoorde, ensovoorts.

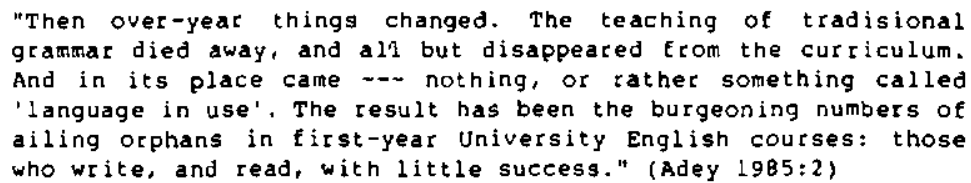

who wite, and read, with little success." (Adey 1985:2)

En wat Afrikaans betref, is die toestand by talle hoërskole nie juis beter nie. Navraag het getoon dat veral die ontleding van sinne in baie gevalle òf vermy òf so half terloops aan bod kom, "omdat dit so min in die eksamen tel". Dieselfde leerlinge moet egter ook die tradisionele rededele ken. Hoe leerlinge rededele kan leez ken sonder om sinsontleding te doen, begryp ek glad nie. Alhoewel hierdie twee aspekte van taalondercig nle die alfa en die omega darvan is nie, mak dit wel 'n baie belangrike onderdeel daarvan uit. En ' $n$ mens $k$ an mar net hoop dat die verouderde leerplanne iewers in die nabye toekoms ' $n$ slag in lyn gebring sal word met ontwikkelings en ontdekkings wat die afgelope par dekades in die taalkunde plaasgevind het.

In die departemente Afrikaans en Nederlands en Engels (Unisa) word daar, benewens die "normalen eerstejaarskursusse, kursusse aangebled wat as "Praktiese Afrikaans" en "Practical English" bekend staan. In albei gevalle is die kursusse meer "prakties" yan aard in dié sin dat min of geen letterkunde aangebied word nie, en dat daar meer aandag gegee word aan die praktiese gebruik van die taal --- 'n soort dienskursus dus. Wat Afrikaans betref, is die akademie se Afrikanse woordelys en spelreēls byvoorbeela een van die belangrikste handboeke.

Vier jaar gelede is daar drie deurgangskursusse ingestel, naamik in afrikaans, Engels en Rekeningkunde. 'n Eerstejaarstudent wat aan die einde van die jaar in geen kursus slaag nie, kon nie weer inskryf vir dieselfde of in ander vak nie, tensy hy één van die drie deurgangskursusse suksesvol afgelé het. Sover dit afrikaans en Engels betref, word hierdie kursusse as 'n Bleerplan by respektiewelik Fraktiese Afrikaans en practical English beskou. In sy referat wat prof. K.J.B. Landman tydens die seminaar op 8 Mei gelewer het, sê hy onder meer dat die bedoeling met die drie deurgangs- 
http://spilplus.journals.ac.za/

\begin{abstract}
J.P. Botha 360
kursusse is orn "potensiële universiteitsmateriaal uit onsuksesvolle studente te red en gereed te mak vir universiteitstudie" (Landman 1985:1) conderstreping deur my -- J.P.B.]. Die feit dat die Rad en Senat van die universiteit hierdie deurgangskursusse ingestel het, toon dat hulle baie bewus geword het van die basiese tekortkominge by 'n groot persentasie eerstejaars, of "lack of development" soos prof. Adey (1985:1) dit gestel het. Die studente wat verplig is om vir so 'n kursus in te skryf, moet dus meesal dinge aanleer wat hulle nog nie vantevore onder die knie gekry het nie, want
\end{abstract}

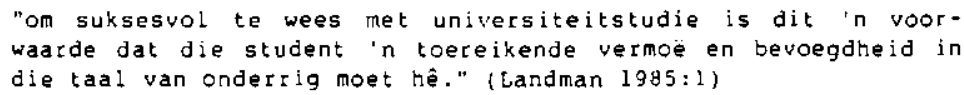

Indien ' $n$ mens in gedagte hou dat eerstejaars wat in Engels of afrikaans net-net geslaag het, wel deeglik leentes en tekorte het sover dit hulle taalbevoegdheid betref, is dit duidelik dat kandidate wat 'n deurgangskursus moet volg, baie groter leemtes en tekorte in dié opsig moet hê.

Die toelatingsvereistes vir Afrjkaans en Nederlands I is soos volg:

1. minstens 408 vir Afrikaans (Eerste taal), Hoër Graad, of

2. minstens 408 in Afrikaans (Tweede taal), HoërGraad, of

3. Praktiese Afrikaans.

Uit Landman se statistiek (1985:4) blyk dit dat die druipsyer vir die nieAfrikaanssprekende Afrikaans en Nederlands I-groep 488 is, en vir die nieAfrikaansprekende groep wat Praktiese Afrikaans (leergang A) geneem het. is dit so hoog as 538 . Tereg vra hy dan (p.6) of die syfers nie dalk ' $n$ aanduiding dacrvan is dat die tweede toelatingsvereiste, dit wil sê minstens 408 in Afrikaans (Tweede taal), Hoër graad, geen warborg is van "'n redelik gevorderde kennis van Afrikaans as skoolvak" nie. Alles dui daarop dat hy gelyk het.

Al is dit moeiljk of selfs onmoontlik om enigsins akkurat vas te stel in hoeverre die doelstellings van normering aan die einde van 'n leerling se skoolloopbaan bereik is, dui protf. Adey en Landman se onderskeie referate wel deeglik, en minstens, aan hoe groot en ernstig die leemtes en tekortkominge ten opsigte van die twee amptelike tale is by naskoolse studente, en prof. Landman se syfers toon aan hoe groot en ernstig die leemites en tekortkominge ten opsigte van Afrikaans by reral nie-Aflikaanssprokendes 
is. Omdat taalonderrig op skool hand a an hand geskied met normering, is dit uit die twee referate duidelik dat normering op skool, in baie gevalle, nie net onvolledig nie, mar ondoeltyeffend tot uiters swak gedoen word. Dit is per slot van sake die grootste rede warom daar in beide landstale nou in "praxtiese xursus", "leeiplan $B^{i}$ ingestel is -.- die Universiteit moet nout doen wat die skool moes gedoen het!

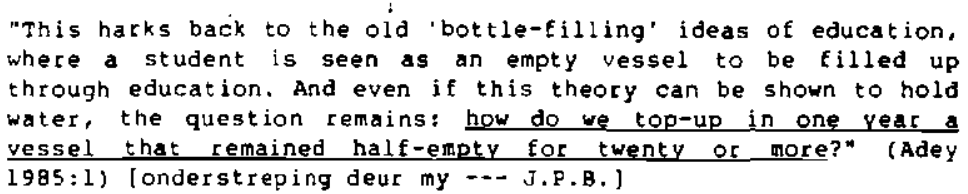

Die departement Ingels het onder meer 'n boekie saamgestel, Supplementary language and comprehension exercises, om minstens te probeer om die bottels voller te maak. Wat af rikaans betref, word daar met behulp van die studiegidse en handboeke gepoog om dit wat nodig is, by te bring. Die norme wat voor in die Afrikaanse woordelys en spelreëls verskyn, word onder meer toegelig, verduidelik en as leerstok aangebied. Dit gaan dus uitsluitlik oor noodsaklike norme in verband met spelling: uitken van afsonderlike woorde, los- en vasskryf van sekere woorde, woordgroepe, sinspatrone en sinsvolgorde. Uit die aard van die saak kan dié onderig slegs voorskrlftelik wees, want die student moet die taal in so ' $n$ mate onder die knie kry dat hy ' $n$ volwardige universiteitstudent kan wees. Dit geld nie net vit die taaldepartemente nie.

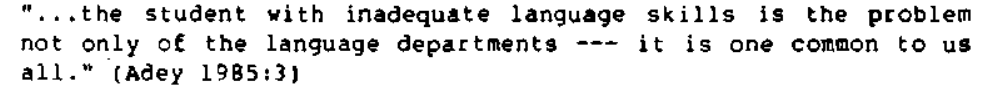

Dit is tog nie net studente wat vir Engels of Afrikans inskrye wat dikwels groot taalvaardigheidsprobleme het nie, en dié tekortxominge moet sulke studente tog ook in ander vakke aan bande lê. Wat in student ook al in ander vakke moet neerskryf in die vorm van ' $n$ verslag, 'n oorsig, 'n verduideliking, 'n uiteensetting, 'n resultaat, 'n bevinding, ensovoorts moet immers. só korrex gestel wees dat sy lesers hom korrex sal verstaan. en dat sy stelwerk veral nie aanleiding sal gee tot misinterpretasie nie.

Dit lyk dus asof die universiteit nie ' $n$ ander keuse net as om (minstens op eerstejaarsviak) benewens sy gewone taak, ook preskriptief te onderrig nie. Adey (1985:3) sê: 
"The poor student does not (pass) --- due primarily to language deficiencies he brings with him to University."

En dit is hierdie "language deficiencies" wat, saam met die onderrig van die taal, normering noodsaaklik mak, want die tekortkominge wat die student sambring universiteit toe --- ten spyte van die standaarde of norme wat as toelatingsuereistes gestel word ... moet uitgewis word.

Een van die vrae wat linguiste mee te make het, is of hulle taal moet beskryf soos dit gebruik word of soos dit grammaties korrek behoort gebruik te word. Soos Radford (1981) dit stel:

"... should he (the linguist) describe what people actually say, or should he attempt to prescribe what he or others think they ought to say? In other words should linguists be descriptive, or prescriptive". (pp.5, 6)

En dan vervolg hy:

"In actual fact, it is hard to see how anyone could defend the prescriptive approach...". (p.6)

Hierdie laaste stelling van hom is egter glad nie so absurd as wat hy voor gee nie. Die linguis wat 'n gegewe taal deeglik bestudeer het en die nodige vaardighede bemeester het om die taal 'korrek' te kan gebruik, is by uitstek die geskikste persoon om, ten opsigte van kleuters, skoolgaande kinders, jongmense, allerlei student en andertaliges, wat almal dié taal van swak tot taamlik goed ken, preskriptief te werk te gaan on hulle taalgebruik by die bestaande of voorgestelde norme aan te pas. Al sou die preskriptiewe, en dus ook normerende onderrig meer toegespits wees op geskrewe taal, is die mondelinge taalgebruik (wat Radford hier blykbaar op die oog het) nie daarvan uitgesluit nie. Daarvan getuig die mondelinge periodes wat minstens van die kleuterskool tot en met matriek deel van die leerplanne uitmaak. Wat Radford dus hier nie in berekening bring nie, is dit wat so vanselfsprekend is dat dit meestal total misgekyk en selfs van vergeet word, naamik: 
http://spilplus.journals.ac.za/

Die 1 inguis wat deskriptief te werk gaan met sy studieobjek is gewoonlik besig on een of meer aspekte van die betrokke taal fonder meer fonologiese, morfoloqiese, sintaktiese en sepantiese aspekte) onder die loep te neem en aan te toon in watter graad dit afwyk van, of ooreenstem met dit wat deur middel van normerende, preskriptiewe bronne as taal (selfs "standaardtaal") tot stand gekom het. Hy beskrye dus ' $n$ taal wat volgens preskriptiewe norme sy beslag gekry net. Dié preskriptiewe norme kom natuurlik nie net van die taalonderwyser (indien daar wel een was) nie, maar van die ouers, die broers en susters, die mats, die omgewing, die sosiale gemeenskap, die kontak met "meerderes", die skole en die kerke.

Hoe die norme ook al by die leerling/student uitkom, uiteindelik is dit nodig dat hy as beskafde mens, soos Van wyk Louw dit in "Raka" stel,

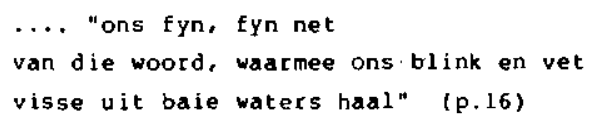

ken.

\section{$7 \quad$ Slotbeskouing}

Uit hierdie voorlopige ondersoek en bespreking kan " $n$ mens minstens ' $n$ paar afleidings makk wat in ' $n$ mindere of meerdere mate waar is ten opsigte van die normering van die gebruik van Afrikaans soos dié praktyk beofen word in die skool en die universiteit:

(i) Die normering van die gebruik van Afrikaans geskied reeds van kleins at en word in die skool doelbews voortgesit; veral deur taalonderwysers.

(ii) Talle negatiewe invloede sou aangetoon kon word soos: fout iewe taalgebruik wat oral voorkom in die sosiale gemeenskap, die verskillende nuusmedia; persone (veral onderwysers) wat hulle moedswillig nie steur aan "korrekte" taalgebruik nie; die onwiligheid van die kinders om (selfs rebelsheid daarteen) die verpligte vak op hoërskool te neem; die groot invloed van Engels op elke terrein van die samelewing.

(iii) Die taalonderwyser lewer dwarsdeur die kind se skoolloopbaan ' $n$ onvervangbare en oneindig waardevolle bydrae tot normering. Dik werk gou 
http://spilplus.journals.ac.za/

i.P. Botha 364

nog doeltreftender gedoen kon word indien (van) die struikelblokke van veral die taalonderrig aan hoërskole uit die weg geruim kon word deur die betrokke owerhede.

(iv) Die toetsing van presies hoe geslaagd en volledig normering plaasgevind het, is moeilik, selfs onmoontlik, maar die resultate van ondoeltreffende normering is opvallend in die taalgebruik van eerstejaarstudente aan universiteite.

(v) Die swak taalgebruik van baie eerstejaarstudente -. meesal mense wat wel aan die minimum toelatingsvereistes voldoen het --- noodsaak tans die voortsetting van normering aan die universiteit.

(vi) Normering van taalgebruik lê die basis vir die latere deskriptiewe bestudering van taal en taalgebruik. 


\section{BIBLIOGRAFIE}

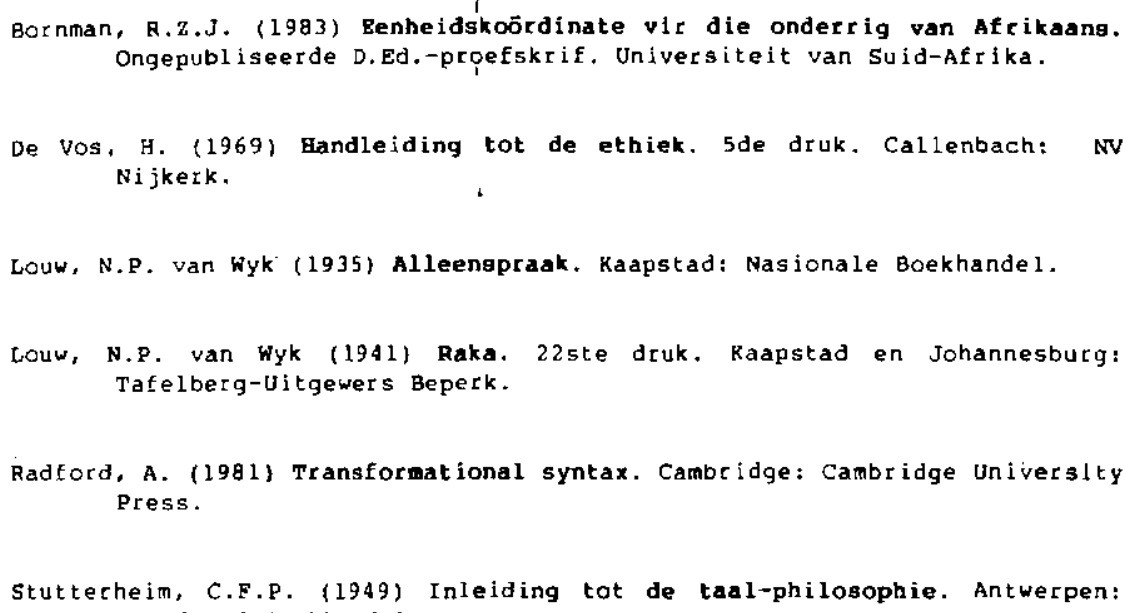
Ongepubliseerde D.Ed.-profefskrif. Universiteit van Suid-Afrika.

De Vos, H. (1969) Eandleiding tot de ethiek. 5de druk. Callenbach: NV Nijkerk.

Louw, N.P. van Wyk (1935) Alleengpraak. Kaapstad: Nasionale Boekhandel.

Louw, N.P. van Wyk (1941) Raka. 22ste druk, Kaapstad en Johannesburg: Tafelberg-Uitgewers Beperk.

Radford, A. (1981) Transformational syntax. Cambeidge: Cambridge Universlty Press.

Stuttecheim, C.F.P. (1949) Inleiding tat de taal-philosophie. Antwerpen: Standaard-Boekhandel.

Swatt, A. (1983) Vakdidakt iek: Afrikaans (B.o.D.). Studiegieds, Unisa.

Van Deventer, J.J. (1979) Betrokkenheld as praagstuk in die literatuuronderrig in die niddelbare akool. Ongepubliseerde M.Ed-rverhandeling, Unisa. 